\section{STUDI KRITIK HADIS TENTANG MELAKSANAKAN SHALAT JUM'AT PADA WAKTU HARI RAYA}

\section{Khairuddin}

Program Pascasarjana UIN Suska Riau

Email:kh4iruddin@yahoo.co.id

\section{Abstract}

Critical Study on Hadist of Perfoeming Jum'at Prayer During I'ed Days: In muslim's community, there is an opinion that when i'ed days are on Friday so there is rukhshah (relief), i.e muslims are not necessary to perform the Friday prayers, even more than thatdhuhur prayer is not mandatory. These assumptions are developed in response to the hadith. Hadith authenticity needs to be investigated by using hadith research method. When observed for the emergence of this tradition based on what was stated in the Hadith, the tradition is referred to as "ahl al-'awall" (remote residents) were estimated when they return to the village where they lived, they would no longer be able to perform Friday prayers with the prophet. Based on the understanding of the causes emergence of this Hadits, the leeway given to the prophet is for those who live far from the place in which the Friday prayer is perfoemed. Rukhshah law is an exception to the law 'azimah' which can be applied whenever there is masyaqqah in mukallaf that if he is still implemented by 'azimah', at least it will bring trouble. In fact, Islam does not give trouble to mukallaf in performing religious teachings.

Keywords: Jum'at Prayer, I'ed Days, and Rukhshah.

\section{Pendahuluan}

Islam adalah agama universal yang mengatur seluruh aspek kehidupan manusia. Keuniversalan Islam tersebut bisa dilihat dar norma dan doktrin-doktrin yang terdapat di dalamnya. Norma-norma tersebut menyangkut hubungan manusia dengan Khaliqnya, manusia dengan manusia dan manusia dengan lingkungannya. Selain itu, keuniversalan Islam juga terlihat dari cakupannya yang tidak hanya mengatur kehidupan duniawi semata, tetapi juga mengandung prinsipprinsip tentang kehidupan akhirat beserta serangkaian peristiwa yang akan dilalui manusia kelak.

Secara umum, keuniversalan Islam tersebut dapat dibagi dalam dua kategori, yaitu akidah dan syari'ah. ${ }^{1}$ Dalam kavlingan syari'ah terdapat pula bagian ibadah yang secara spesifik mengatur hubungan orang muslim dengan Khaliqnya, hubungan sesama muslim, hubungan orang muslim denngan sesama manusia, hubungan orang muslim dengan alam dan hubungan orang muslim dengan kehidupannya. ${ }^{2}$ Shalat Jum'at merupakan salah satu bentuk ibadah usbu'iyah yang dasar pelaksanaannya berdasarkan al-Qur'an dan praktek yang dilakukan rasulullah saw.

Dalam masyarakat muslim berkembang pendapat, baik di kalangan ilmuan maupun masyarakat awam, apabila pada hari Jum'at bertepatan dengan pelaksanaan hari raya ('id al-Adha atau 'id al-Fitri), maka terdapat rukhshah untuk tidak melaksanakan shalat Jum'at, bahkan lebih dari itu shalat dhuhur-pun menjadi tidak wajib. ${ }^{3}$

Asumsi ini ini berkembang ternyata bukan hanya sebagai hasil ijtihad ataupun praduga yang tidak bisa ditolerir, tetapi muncul sebagai respon mereka terhadap hadis nabi. Sebagai seorang muslim yang

${ }^{1}$ Pengklasifikasian Islam pada akidah dan syari'ah ini, antara lain dikemukanan oleh Mahmud Syaltut dengan bukunya al-Islam, Aqidah wa Syari'ah, (Cairo: Daar al-Qalam, 1966)

${ }^{2}$ Lihat: Ibid., hlm. 12

${ }^{3}$ Pendapat dimaksud menjadi salah satu topik kajian dalam kitab-kitab fiqh; antara lain dapat dilihat tulisan Sayyid Sabiq, Fiqh al-Sunnah, (Beirut: Daar alFikr, 1995), jilid I, hlm. 239. Juga dapat dilihat Ibn Rusyd, Bidayat al-Mujtahid fi Nihayat al-Muqtashid, (Beirut: Daar al-Fikr, t.th.), jilid I, hlm. 159 
telah meyakini kewajiban shalat Jum'at, rasanya hadis tersebut perlu diteliti keotentikannya dengan menggunakan metode penelitian hadis seperti diuraikan di bawah ini.

\section{Takhrij al-hadis}

\section{Takhrij al-matn}

Dalam rangka penelitian matn al-hadis ini, dilakukan dengan beberapa metode penelitian matn al-badis, seperti melalui kosa kata, tema, rawi al-a'la, lafadh pertama dari matn al-hadis dan sifat yang dhahir. Namun sebelumnya untuk memudahkan faham, terlebih dahulu dikemukakan matn al-hadis sebagaimana dapat dilihat di bawah ini:

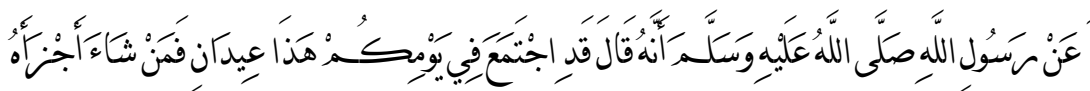

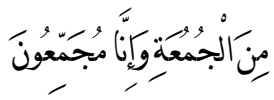

Artinya: Rasulullah saw. bersabda; hari ini bertepatan terkumpul dua hari raya dalam satu waktu. Barangsiapa yang mau, sudah mamadai baginya Jum'at dan kami menggabungkannya.

\section{a. metode bi al-lafzh}

Dengan menelusuri kata “

¿ ", berdasarkan petunjuk yang diperoleh dari Mu'jam al-Mufahras li alfaz al-Hadis, hadis ini dijumpai pada kitab hadis; Sunan Abu Daud, jilid pertama, kitab Shalat, bab apabila bersamaan Jum'at dan hari raya pada satu waktu (hari), hadis nomor 1073, halaman 281; Sunan Ibn Majah, jilid pertama, kitab mendirikan shalat dan shalat-shalat sunat, bab apabila berhimpun dua hari raya pada satu hari, hadis nomor 1311, halaman $415-416 .{ }^{4}$

Selain itu, dengan matan yang sedikit berbeda, tetapi maknanya sama, hadis ini juga dapat dijumpai pada kitab hadis; Shahih Bukhari, jilid III, kitab Qurban, bab memakan daging qurban dan yang berlebih, hadis nomor 5572, halaman 344; Muwaththa' Malik, jilid I, kitab dua hari raya, bab seruan pergi shalat, hadis nomor 5, halaman 179; Sunan Nasai (Syarab alSuyuthiy), jilid III, kitab shalat dua hari raya, bab keringanan meninggalkan jum'at bagi orang yang berhadapan dengan hari raya, nomor bab 32, nomor hadis 1591, halaman 135; Sunan al-Darimi, jilid I, kitab shalat, bab apabila terhimpun dua hari raya pada satu hari, halaman $378 .{ }^{5}$ Untuk lebih jelasnya dapat dilihat pada tabel di bawah ini:

\begin{tabular}{|c|c|c|c|c|c|c|}
\hline \multicolumn{6}{|c|}{ لفظ إجتمع } & \multirow{2}{*}{ رقم } \\
\hline المزء /ص & رقم الصيث & قـم البلب & بلب & كنب & إليث & \\
\hline $344 / 3$ & 5572 & 16 & مهو لإضاهح & إdiاجى & $\dot{\tau}$ & 1 \\
\hline- & - & - & - & - & م & 2 \\
\hline $281 / 1$ & $\begin{array}{c}1070,71,72 \\
73\end{array}$ & - & إذا وفف ... & صلاة & د & 3 \\
\hline- & - & - & - & - & ت & 4 \\
\hline $135 / 3$ & 1591,92 & 32 & رخصة ... & عدن & ن & 5 \\
\hline $\begin{array}{c}/ 1 \\
415,16\end{array}$ & $1310,11,12$ & 166 & إذاجتمع ... & إفلة ... & $\Phi$ & 6 \\
\hline $378 / 1$ & - & - & إذا جتمع ... & صلاة & נى & 7 \\
\hline $179 / 1$ & 5 & - & إذا دهى ... & عدن & b & 8 \\
\hline
\end{tabular}

${ }^{4}$ A.J. Wensinck, Mu'jam al-Mufahras li Alfazh al-Hadis al-Nabawiy, (Leiden: EJ. Brill, 1967), jilid I, hlm. 368

${ }^{5}$ Ibid. 


\begin{tabular}{|l|l|l|l|l|l|l|}
\hline- & - & - & - & - & 8 & 9 \\
\hline
\end{tabular}

b. metode bi harf al-awwal min awwal al-lafz̧bi

Matan hadis ini dimulai dengan kata “ $\mathbf{2}$. ق“. Melalui penelusuran hadis berdasarkan awal lafazh dengan melihat huruf $\boldsymbol{\Theta}$ , berdasarkan informasi yang diperoleh dari kitab Al-jami' alShaghir fi Ahadis al-Basyar al-Nazariyah, hadis ini terdapat pada kitab hadis; Sunan Abu Daud, Sunan Ibn Majah, dan AlMustadrak Hakim 'ala al-Shahihaini, jilid pertama, kitab Jum'at, hadis nomor 1064/39, halaman 425-426.

Untuk lebih jelasnya dapat dilihat pada tabel di bawah ini:

\begin{tabular}{|c|c|c|c|c|c|c|c|}
\hline \multicolumn{7}{|c|}{ ترف لأول من لفظ لأول (ق) } & \multirow{2}{*}{ رقم } \\
\hline ص & 5] & | رقم ال]يث & رقم البلب & بلب & كتب & تيث & \\
\hline 281 & 1 & $1070,71,72,73$ & - & إذا وفق ... & صلاة & د & 1 \\
\hline $\begin{array}{l}-1415 \\
1416\end{array}$ & 1 & $1310,11,12$ & 166 & |إذا اجمع ... & إقلة ... & 0 & 2 \\
\hline $\begin{array}{c}-425 \\
426\end{array}$ & 1 & 1064 & 39 & - & إ]معة & ك & 3 \\
\hline
\end{tabular}

c. metode bi al-maudhu'

Melalui metode ini, berdasarkan informasi yang diperoleh dari kitab Miftah Kunuz al-Sunnah, hadis di atas terdapat pada tema “

" dalam kitab-kitab hadis; Sunan Abu Daud, kitab shalat, bab apabila bertepatan hari Jum'at dengan hari raya; Sunan Ibn Majah, kitab iqomah, bab apabila terhimpun dua hari raya pada satu hari;

${ }^{6}$ Imam al-Hafizh Khadim al-Sunnah wa Qani' al-Bid'ah Jalal al-Din Abd alRahman ibn Abu Bakar al-Suyuthi, selanjutnya ditulis Suyuthi, Al-Jami' alShaghir fi Ahadis al-Basyar al-Nazariyah, (Singapura: Syirkah al-Nur Asia, t.thlm.), jilid I, hlm. 85
Sunan Nasai, kitab shalat dua hari raya, bab keringanan meninggalkan shalat Jum'at bagi orang yang mendapatkan jum'at dan hari raya pada satu waktu; Muwaththa' Malik, perbuatan pada hari raya, bab seruan pergi shalat; Sunan Darimi, kitab shalat, bab apabila terhimpun dua hari raya pada satu waktu; Musnad Ahmad ibn Hanbal, jilid IV, halaman 372 dan Musnad Abu Daud Thayalisi, hadis nomor $685 .^{7}$

Untuk lebih jelasnya dapat dilihat pada tabel di bawah ini:

\begin{tabular}{|c|c|c|c|c|c|c|c|}
\hline \multicolumn{7}{|c|}{ بالإضوضوع " العيد" } & \multirow{2}{*}{ رقم } \\
\hline صفة & s) & رقم الصيث & رقم البب & بلب & كنب & إليث & \\
\hline 281 & 1 & $1070,71,72,73$ & - & 210 & 2 & بد & 1 \\
\hline 135 & 3 & 1591,92 & 32 & 33 & 19 & شن & 2 \\
\hline 415,16 & 1 & $1310,11,12$ & 166 & 166 & 5 & مج & 3 \\
\hline 378 & 1 & - & - & 225 & 2 & م & 4 \\
\hline 179 & 1 & 5 & - & 5 & 10 & ما & 5 \\
\hline 372 & 4 & - & - & & - & هم & 6 \\
\hline & & 685 & & & - & b & 7 \\
\hline
\end{tabular}

Lambang yang digunakan dalam Miftah Kunuz al-Sunnah ini berbeda dengan lambang yang digunakan dalam Mu'jam al-Mufahras li Alfaz̧h al-Hadits. Lambang بـ menunjukkan Sunan Abu Daud, lambang vimenunjukkan Sunan Nasai, lambang جomenunjukkan Sunan Ibn Majah, lambang o menunjukkan Sunan al-Darimi, lambang L omenunjukkan Muwaththa' Imam Malik, lambang menunjukkan Musnad Imam Ahmad dan sedangkan huruf $\boldsymbol{b}$ menunjukkan Musnad Abu Daud al-Thayalisi.

${ }^{7}$ A.J. Wensinck dan ditambah oleh Fuad Abd al-Baqi, Miftah Kunuz alSunnah, (Cairo: Daar al-Hadis, 1996) cet. ke-3, hlm. 368 


\section{d. metode bi rawi al-a'la}

Dengan menelusuri hadis ini dengan metode rawi al-a'la, Zaid ibn Arqam, dengan menggunakan kitab Musnad Ahmad ibn Hanbal, hadis ini terdapat pada jilid IV, halaman 372.

Untuk lebih jelasnya dapat dilihat pada tabel berikut:

\begin{tabular}{|c|c|c|c|c|}
\hline الصفحة & إ] & حيث & راوي لأعلى & رقم \\
\hline 372 & راع & مسند ألّد لين حنلى & زيد لن أرقم & 1 \\
\hline - & - & مسند ألّد لن حنل & ابوهيرة & 2 \\
\hline- & - & مسند ألّد لن حنل & لين عبل & 3 \\
\hline- & - & مسند ألّد لن حنبل & لن عمر & 4 \\
\hline
\end{tabular}

e. metode bi al-shifat al-dhahir

Bila dilihat ciri utama hadis di atas, maka hadis ini termasuk dalam kelompok hadis hukum. Dengan demikian, juga dapat ditemukan dalam kitab Bulugh al-Maram min Adillat al-Ahkam, karya al-Hafidh ibn Hajar al-'Asqalani, hadis nomor 483, halaman 92.

Adapun sanad dan matan hadis secara lengkap, berdasarkan informasi di atas, hadis-hadis tersebut adalah:

1. Shahih Bukhari

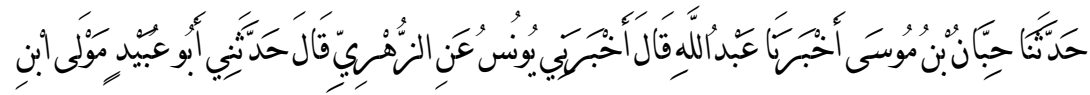

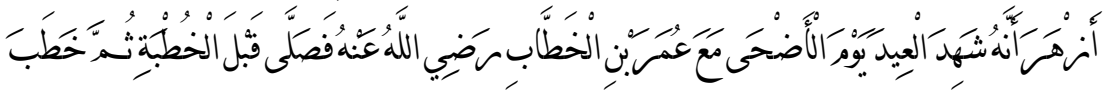

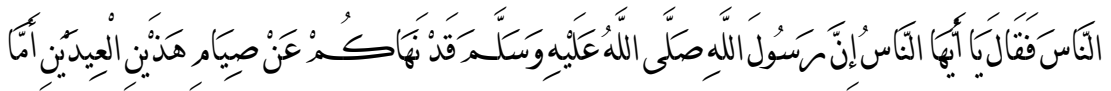

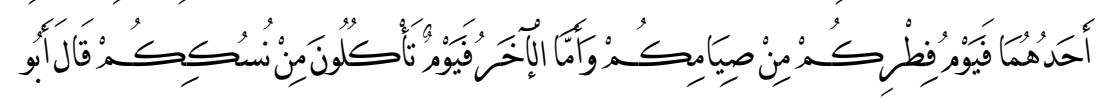

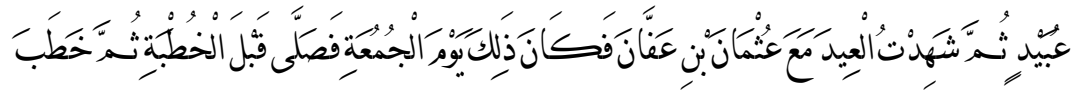

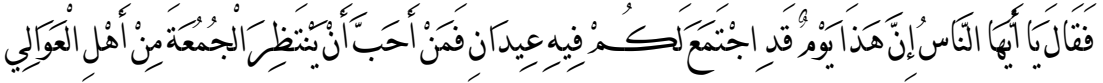

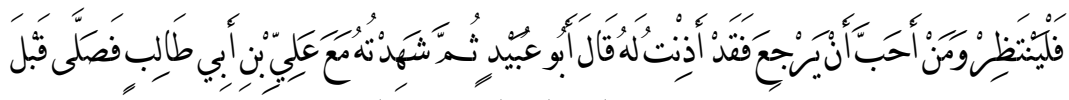

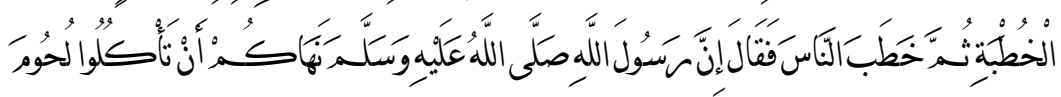

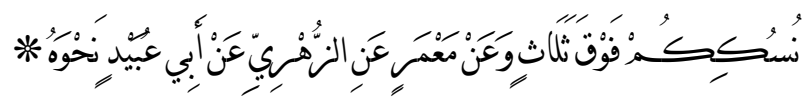

2. Sunan Abu Daud

a $(1070)$

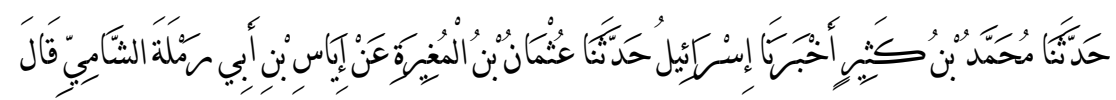

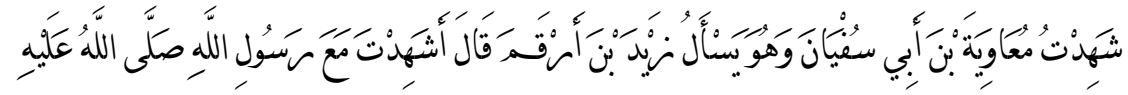

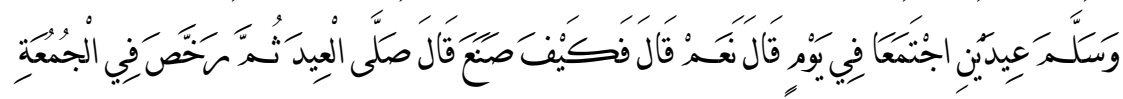

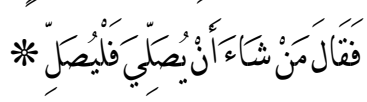

b (1071)

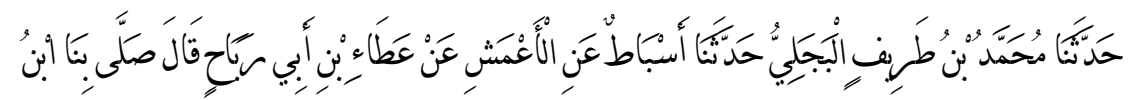

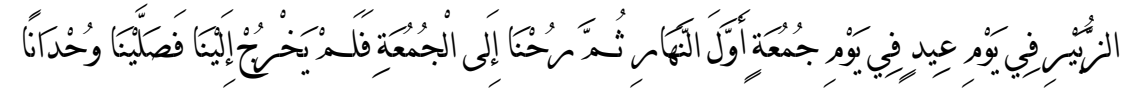

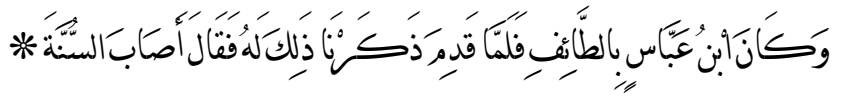

c (1072) 


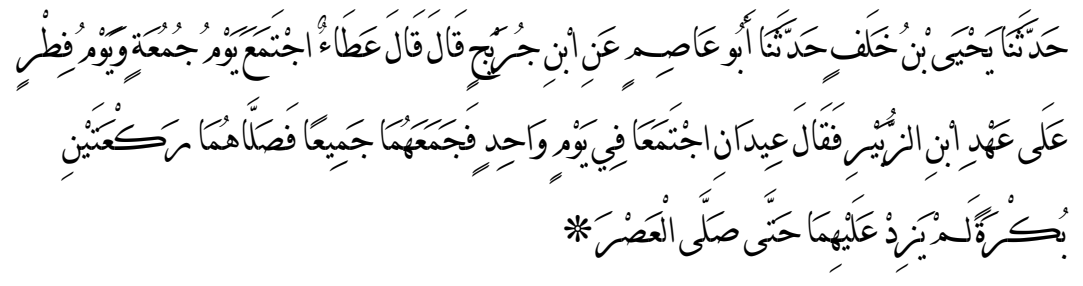

d (1073)

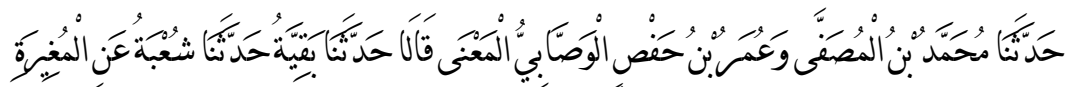

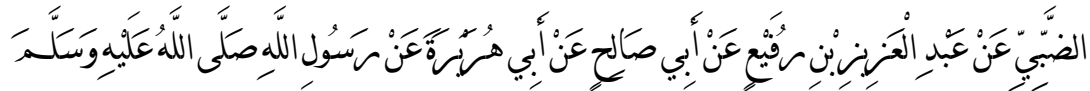

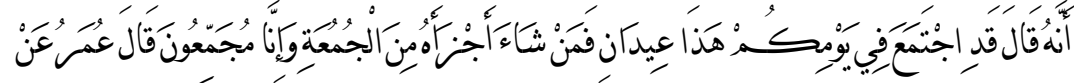

شُعْبَة

3. Sunan Ibn Majah

a. (1310)

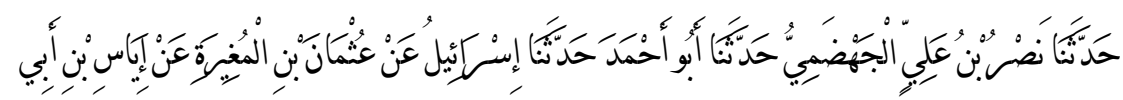

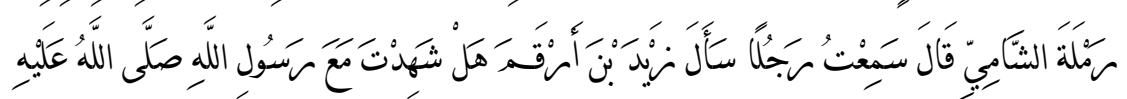

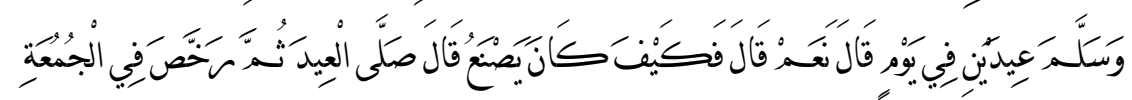

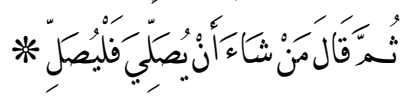

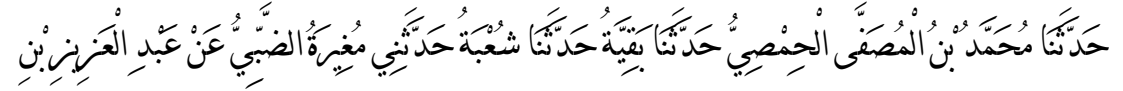

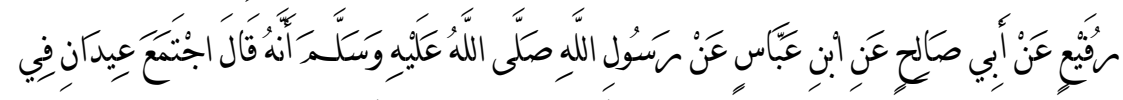

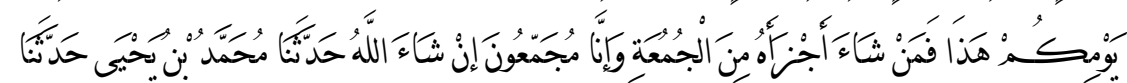

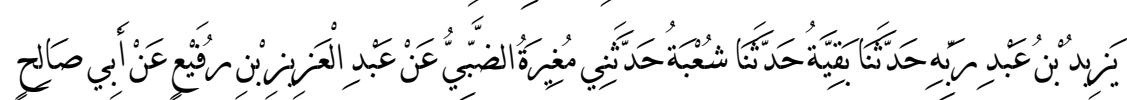

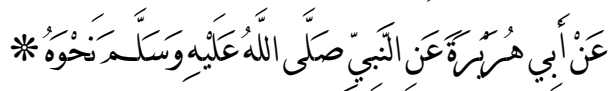

c. 1302

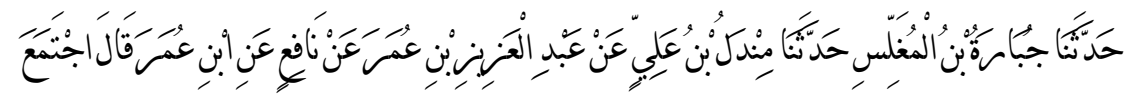

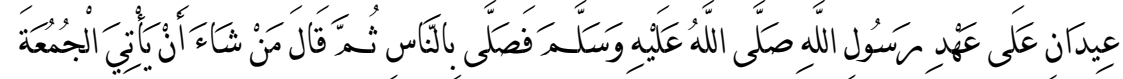

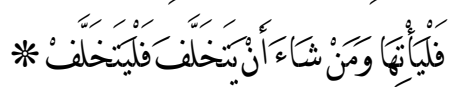

4. Sunan Nasaiy

a.1591

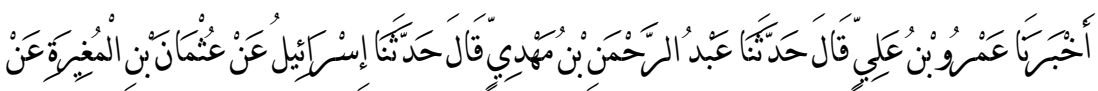

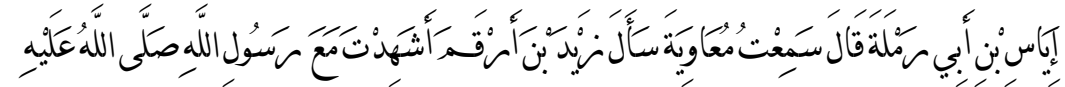

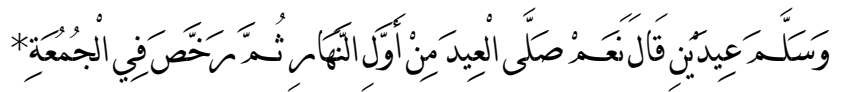




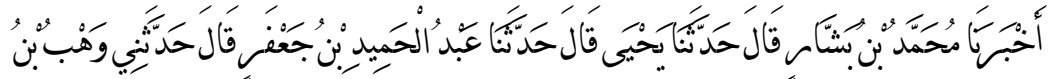

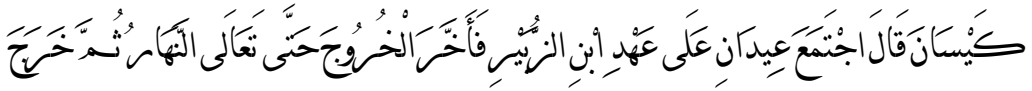

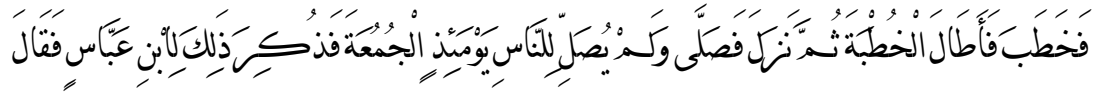

$$
\begin{aligned}
& \text { أصكابكالستّنَ }
\end{aligned}
$$

5. Sunan al-Darimi

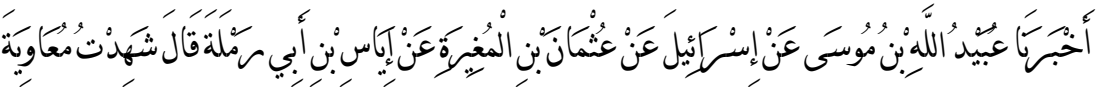

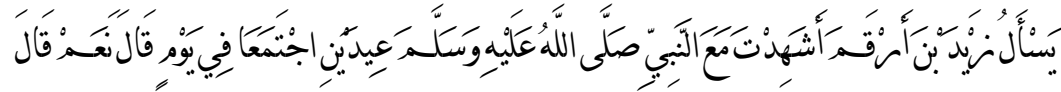

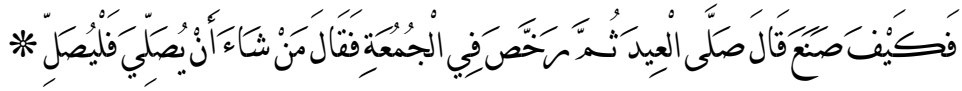

6. Muwaththa' Malik

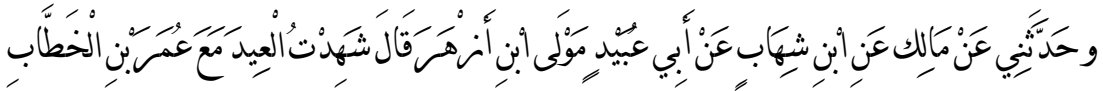

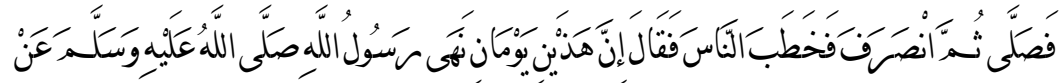

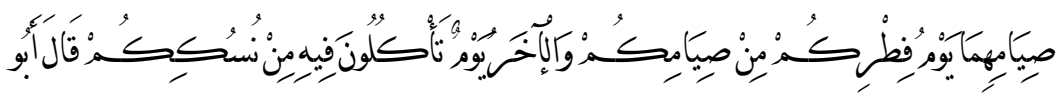

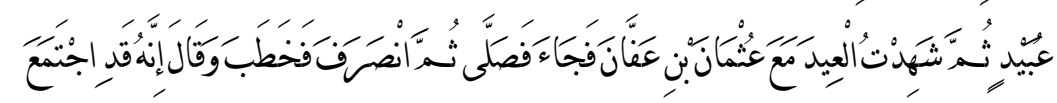

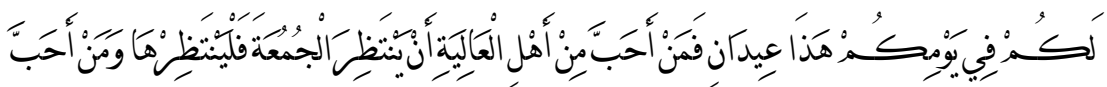

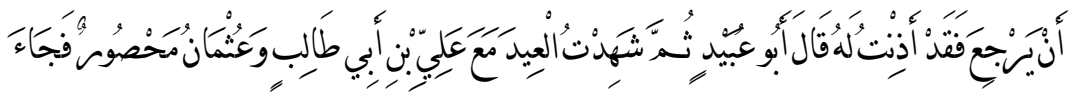

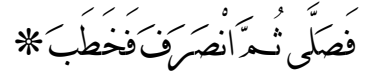

7. Musnad Ahmad ibn Hanbal

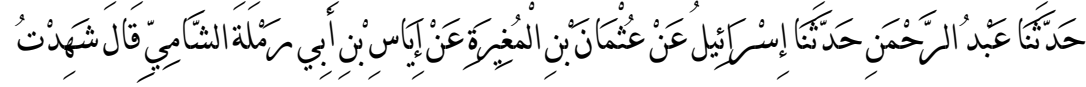

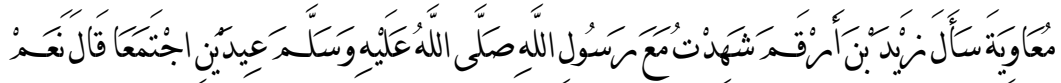

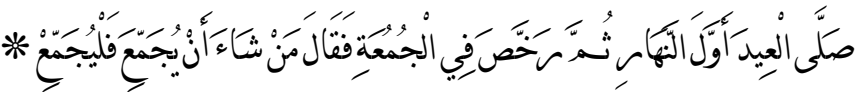

8. Mustadrak Hakim

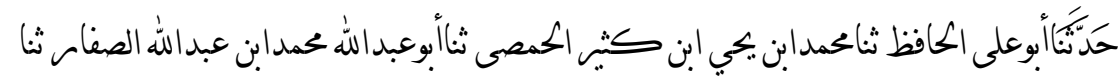

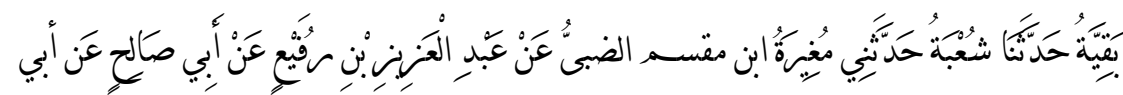

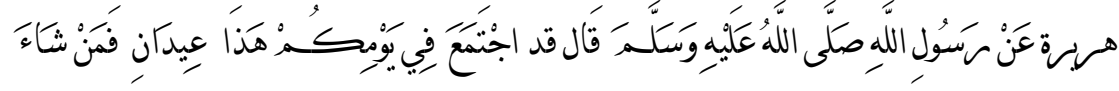

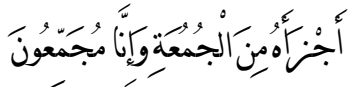

\section{Takhrij al-sanad}

Sebelum diadakan takhrij al-sanad selanjutnya, untuk memudahkan dalam penelitiannya, maka terlebih dahulu dilakukan i'tibar. Berhubung begitu banyaknya riwayat yang membicarakan topik ini, maka dalam penelitian sanad selanjutnya penulis hanya mengambil hadis riwayat Abu Daud, nomor 1073 dan pada makalah ini dituliskan pada poin $\mathrm{d}$.

Dalam mengemukakan periwayatan, Abu Daud menyandarkan riwayatnya kepada dua periwayat sebelumnya, yakni Muhammad ibn Mushaffa dan Umar ibn Hafsh. Kedua riwayat yang disandari Imam Abu Daud tersebut dalam ilmu hadis disebut sebagai sanad pertama. Dengan demikian, maka sanad terakhir dalam hadis tersebut adalah Abu Hurairoh, yakni periwayat pertama karena dia sebagai sahabat nabi yang berstatus sebagai pihak pertama yang menyampaikan riwayat hadis tersebut. Berikut 
ini dikemukakan urutan periwayat dan sanad untuk hadis yang akan diteliti:

\begin{tabular}{|c|l|l|l|}
\hline No & \multicolumn{1}{|c|}{ Nama Periwayat } & Urutan Periwayat & Urutan Sanad \\
\hline 1 & Abu Hurairah & Periwayat I & Sanad VII \\
2 & Abu Shalih & Periwayat II & Sanad VI \\
3 & 'Abd al-'Aziz & Periwayat III & Sanad V \\
4 & Mughirah al-Dhibbi & Periwayat IV & Sanad IV \\
5 & Syu'bah & Periwayat V & Sanad III \\
6 & Baqiyah & Periwayat VI & Sanad II \\
7 & Umar ibn Hafsh & Periwayat VII & Sanad I \\
8 & Muhammad ibn Mushaffa & Periwayat VII & Sanad I \\
9 & Abu Daud & Periwayat VIII & Mukharrij \\
\hline
\end{tabular}

Pada skema di atas, dapat dilihat periwayat pertama sampai dengan keenam, masing-masing hanya satu orang. Sedangkan pada periwayat ketujuh atau sanad pertama terdapat dua orang. Dengan demikian, maka periwayatan tersebut bercabang pada Baqiyah sebagai periwayat keenam, atau sanad kedua.

Dalam riwayat ini, juga terdapat perbedaan lambang seperti 'an, haddatsani, haddatsana dan tsana. Ini artinya bahwa terdapat perbedaan methode periwayatan yang digunakan dalam hadis tersebut. Adapun skema sanad masing-masing hadis dapat dilihat di bawah ini:

\section{Tarikh al-ruwah}

1. Abu Hurairah
Nama aslinya adalah Abdurrahman ibn Shohor al-Dausi alYamani $^{8}$, lahir di Yaman tahun 19 SH dan wafat tahun $59 \mathrm{H}$. Abu Hurairah merupakan kuniyah yang diberikan Rasul kepadanya. Ia merupakan salah seorang sahabat Nabi. Ia masuk Islam pada saat perang Khaibar, bulan Muharram tahun ke-7 H.

Abu Hurairah meriwayatkan hadis langsung dari Nabi Muhammad saw. juga dari Abu Bakar al-Shiddiq, Umar ibn alKhattab, Fadhal ibn Abbas ibn Abd al-Muthallib, Ubai ibn Ka'ab, Usamah ibn Zaid, Aisyah, Nadhrah ibn Abu Nadhrah al-Ghiffari dan Ka'ab al-Ahbar. Adapun ulama yang meriwayatkan hadis dari Abu Hurairah sangat banyak sekali, menurut Bukhari lebir dari delapan ratus orang, antara lain; anaknya al-Muharrir, Ibn Abbas, Ibn Umar, Anas, Watsilah, Jabir, Marwan ibn Hakam, Qubaidhah ibn Dzuwaib, Sa'id ibn al-Musayyab, Salman al-Agirr, Qais ibn Abu Hazim, Malik ibn Abu Amir al-Asbahi, Abu Usamah ibn Sahl ibn Hanif, Abu Idris al-Khulaniy, Abu Utsman al-Hindiy, Abu Sofyan Maula ibn Abu Ahmad, Abu Rafi' al-Shaig, Abu Zar'ah ibn Amr ibn Jarir,Yusuf ibn Mahiq, Haitsan ibn Abu Sinan, Yazid ibn Harmaz, Abu Hazim al-Asyja'iy, Abu Bakr ibn Abd al-Rahman ibn al-Harits ibn Hisyam, Abu Timyah al-Hujaimiy, Yazid ibn al-

${ }^{8}$ Mengenai nama Abu Hurairah, begitu pula nama bapaknya terdapat perbedaan di kalangan penulis riwayatnya. Ada yang mengatakan namanya Abdurrahman ibn Ghinam, Abdullah ibn 'Aid, ibn 'Amir, ibn 'Amr, Sikkin ibn Rozmah, ibn Hani', ibn Tsarmil, ibn Shokhr, 'Amir ibn Abd Syams, ibn Amiir, Yazid ibn 'Asyriqoh, 'Abd Syams, Ghinam, Ubaid ibn Ghinam, Amr ibn Ghinam, ibn Amir, Said ibn al-Harits. Menurut Hisyam, namanya adalah Amiir ibn Amir ibn Tharif ibn Ayyan ibn Abu Sha'ab ibn Hunaid ibn Sa'ad ibn Tsa'labah ibn Salim ibn Fahm ibn Ghinam ibn Dus. Menurut pendapat lain lagi, ketika di masa jahiliyah namanya adalah Abd Syams dan kuniyahnya Abu al-Aswad, setelah Islam Rasulullah mengganti namanya dengan Abdullah dan memberinya kuniah Abu Hurairahlm. Lihat: Imam al-Hafiz Syaikh al-Islam Syihab al-Din Ahmad ibn Ali ibn Hajar al-Asqalani (selanjutnya ditulis Asqalani), Tahzib al-Tahzib, (Beirut: Daar al-Fikr, 1984) cet. I, jilid 12, hlm. 288 
Asham, Musa ibn Wardan, Abu al-Syi'sta' al-Maharibi, Abu Shaleh, Abu Ghathfan ibn Tharif al-Marwiy dan lain sebagainya.

Bukhari, Muslim dan Nasai meriwayatkan hadis yang berasal dari Zuhri dari Said ibn Musayyab dan Abu Salamah ibn Abd alRahman ibn 'Auf bahwa pada diri Abu Hurairah terdapat tandatanda kenabian, ia periwayat hadis yang lebih kuat hafalannya pada waktu itu dan setiap yang diriwayatkan sahabat semuanya juga diriwayatkan Abu Hurairah. ${ }^{10}$ Thalhah berkata Abu Hurairah mendengar dari Rasulullah sesuatu yang tidak pernah kami dengar. Ibn Umar berkata Abu Hurairah lebih baik dan lebih mengetahui dari saya. ${ }^{11}$

Berdasarkan kaidah Sلىصطبة (setiap sahabat dinilai adil), maka Abu Hurairah sebagai sahabat dinilai adil.

Selain penilaian di atas, kelebihan sahabat Rasulullah saw juga dapat dilihat dalam penjelasan al-Qur'an surat al-Taubat ayat 100 seperti di bawah ini:

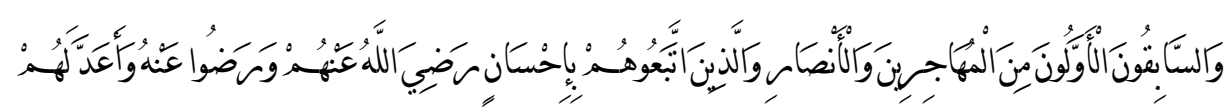

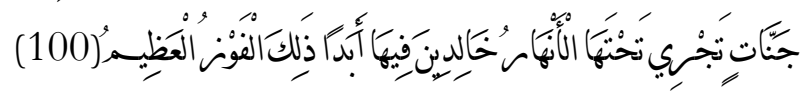

Artinya: Orang-orang yang terdabulu lagi yang pertama-tama (masuk. Islam) di antara orang-orang mubajirin dan anshar dan orang-orang yang mengikuti mereka dengan baik, Allah ridha kepada mereka dan merekapun ridha kepada Allah dan Allab menyediakan bagi mereka surga-surga yang mengalir sungai-sungai di dalamnya; mereka kekal di

${ }^{9}$ Ibid., hlm. 289-290

${ }^{10}$ Ibid.

${ }^{11}$ Ibid., hlm. 291 dalamnya selama-lamanya. Itulah kemenangan yang besar. (QS: Al-Taubat; 100)

Ketika menafsirkan ayat ini al-Qurthubi menjelaskan bahwa yang termasuk golongan pertama dari sahabat itu adalah yang ikut menyaksikan bai'at al-ridwan, yang menyaksikan perpindahan qiblat, yang ikut dalam peperangan Badar dan pjuga perang Uhud. ${ }^{12}$

Selain ayat di atas, masih ada lagi ayat al-Qur'an yang menjelaskan keutamaan para sahabat dan tabiin, seperti;

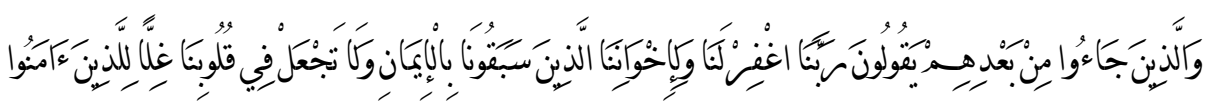

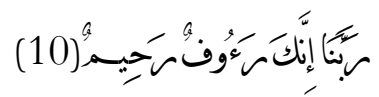

Artinya: Dan orang-orang yang datang sesudab mereka (Mubajirin dan Anshar), mereka berdoa: "Ya Tuhan kami, beri ampunlah kami dan saudara-saudara kami yang telah beriman lebih dabulu dari kami, dan janganlah Engkau membiarkan kedengkian dalam hati kami terhadap orang-orang yang beriman; Ya Tuban kami, sesunggubnya Engkau Maha Penyantun lagi Maha Penyayang". (QS: Al-Hasyar; 10)

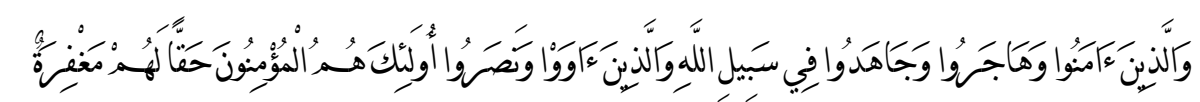

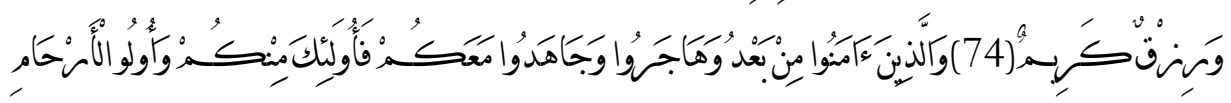

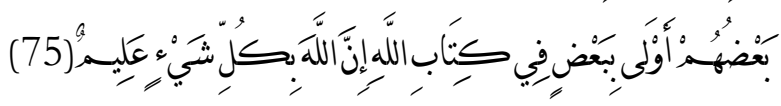

Artinya: Dan orang-orang yang beriman dan berhijrah serta berjihad pada jalan Allah, dan orang-orang yang memberi tempat kediaman dan memberi pertolongan (kepada orang-orang muhajirin), mereka itulah orang-orang yang benar-benar beriman. Mereka memperoleh ampunan dan rezki (ni'mat) yang mulia. QS: Al-Anfal; 75)

${ }^{12}$ CD-Room Holy Qur'an versi 6.5 plus. 
Berdasarkan informasi yang dijelaskan oleh al-Qur'an di atas, maka sahabat dan para tabiin memiliki kelebihan daripada ummat Islam periode berikutnya. Kalau sahabat memiliki kelebihan dan Abu Hurairah adalah merupakan salahseorang sahabat nabi, dengan demikian Abu Hurairahpun memiliki kelebihan dan dapat dinilai sebagai periwayat yang adil.

\section{Abu Shaleh}

Nama lengkapnya adalah Dzakwan Abu Shaleh al-Samani alZiyat al-Madani maula Juwairivah binti al-Ahmas al-Ghatfani. Tidak dijelaskan tentang tahun kelahirannya. Ia ikut menyaksikan pemilihan Utsman ibn Affan, dan wafat pada tahun $101 \mathrm{H}^{13}$

Abu Shaleh meriwayatkan hadis dari Sa'ad ibn Abu Waqqash, Abu Hurairah, Abu Darda', Abu Said al-Khudri, 'Uqail ibn Abu Thalib, Jabir, Ibn Umar, Ibn Abbas, Aisyah dan lainnya. Ulama yang meriwayatkan hadis darinya antara lain; anak-anaknya seperti Suhail dan Shalih, Abdullah, 'Atha' ibn Abu Robah, Abdullah ibn Dinar, Zaid ibn Aslam, Abd al-Aziz ibn Rofi', 'Amr ibn Dinar, alZuhri, Yahya ibn Sa'id al-Anshari. ${ }^{14}$

Abdullah ibn Ahmad berkata berdasarkan informasi bapaknya, ia (Abu Shalih) tsiqat-tsiqat manusia yang lebih mulia dan lebih tsiqat; Ibn Main ia adalah tsiqat; Abu Hatim, tsiqat baik hadisnya dan bisa dijadikan hujjah; Abu zar'ah, tsiqat istiqamah dala mmasalah hadis; Ibn Sa'ad, tsiqat dan banyak hadisnya; al-Saji, tsiqat dan benar; al-Harobi, ia (Abu Shalih) termasuk yang tsiqat dan demikian pula komentar Ibn Hibban dalam kitab al-

\footnotetext{
${ }^{13}$ Ibid., jilid III, hlm. 190

${ }^{14}$ Ibid.
}

Tsiqatnya. ${ }^{15}$ Masih banyak lagi komentar ulama yang mengatakannya tsiqat.

Dari komentar ulama terhadap pribadi Abu Shalih sebagaimana yang dijelaskan di atas, maka dapat dikatakan bahwa Abu Shalih adalah periwayat yang tsiqat.

\section{Abd al-Aziz}

Nama lengkapnya adalah Abd al-Aziz ibn Rafi' al-Asadiy Abu Abdullah al-Makkiy al-Thaifiy. Ia menetap di Kufah dan wafat pada tahun 130 H. ${ }^{16}$

Abd al-Aziz meriwayatkan hadis dari; Anas, Ibn Zubir, Ibn Abbas, Ibn Umar, Abu al-Thufail, Zaid ibn Wahab, Tamim ibn Tharafah, Umaiyah ibn Shafwan al-Jamhiy, Syidad ibn Mu'qal, Ibn Abu Malikah, Abdullah ibn Abu Qatadah, Ubaidillah ibn alQibthiyah, Abu Shaleh, Atha' ibn Abu Robah dan lainnya. Ulama yang meriwayatkan hadis darinya; Amr ibn Dinar (sekaligus sebagai gurunya), al-A'masy, al-Mughirah, Abu Ishak al-Saibaniy, Israil ibn Thuhman, Syu'bah, Hasan ibn Shaleh, Syarik dan lain sebagainya. ${ }^{17}$

Bukhari berkata berasal dari Ali ia (Abd al-Aziz) memiliki enam puluh hadis; berkata Ahmad, Yahya, Abu Hatim dan Nasaiy, tsiqah; Jarir berkata, ia meriwayatkan lebih dari 90 hadis; al-'Ijli berkata, tsiqat; Ya'kub ibn Syaibah berkata hadisnya kuat dan bisa dijadikan hujjah. ${ }^{18}$

\section{${ }^{15}$ Ibid.}

${ }^{16}$ Mengenai tahun wafatnya terdapat perbedaan pendapat. Menurut Mathin, ia (Abd al-Aziz) wafat pada tahun $130 \mathrm{H}$, sedangkan menurut Ibn Hibban dalam kitab al-Tsiqat-nya, Abd al-Aziz wafat setelah tahun $130 \mathrm{H}$, namun Ibn Hibban tidak menyebutkan tahunnya. Lihat; Ibid., jilid VII, hlm. 301
${ }^{17}$ Ibid.
${ }^{18}$ Ibid. 
Berdasarkan penilaian yang diberikan oleh beberapa ulama hadis sebagaimana yang dimuat di atas, ternyata tidak ada seorangpun yang mentajrihkannya. Dengan demikian, maka dapat dikatakan bahwa Abd al-Aziz adalah 'adil.

\section{Mughiroh}

Nama lengkapnya adalah Mughirah ibn Miqsam al-Dhibbiy Maula Abu Hisyam al-Kufi al-Faqih. Menurut satu pendapat ia (Mughirah) lahir dalam keadaan buta. Ia wafat pada tahun 133 H. ${ }^{19}$

Mughirah meriwayatkan hadis dari; bapaknya, Abu Wail, Abu Ruzain al-Asadiy, Ummi Musa sariyah Ali, Ibrahim al-Nakhaiy, Amir al-Sya'bi, Mujahid, Ma'bad ibn Khalid, Harits al-Ikliy, Samak ibn Harb, Syubak al-Dhibbiy, Abd al-Aziz, Abd al-Rahman ibn Abu Naim dan lainnya. Ulama yang meriwayatkan hadis darinya antara lain; Sulaiman al-Taimiy, Syu'bah, al-Tsauriy, Ibrahim ibn Thahman, Isroil, Zaidah ibn Qudamah, Zuhair ibn Mu'awiyah, Sa’ir ibn al-Khams, al-Mufadhdhal ibn Mahlahal, Hasyim, Jarir, Ibn Fadhil, Abu 'Awanah, Khalid ibn Abdullah dan lainnya.

Adapun komentar Kritikus hadis terhadap Mughirah dapat dilihat pada tabel di bawah ini:

\begin{tabular}{|c|c|c|c|}
\hline No & Nama Kritikus & تحلبل & ]יש \\
\hline 1 & Hajjaj ibn Muhammad & 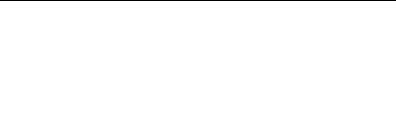 & - \\
\hline 2 & Ibn Fadhil & - & يطلس \\
\hline 3 & Abu Bakar ibn 'Iyasy & 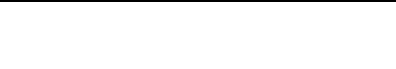 & - \\
\hline 4 & Ibn Jarir dari Mughirah & ماقع [مسلعيشوفنسينة & - \\
\hline
\end{tabular}

${ }^{19}$ Mengenai tahun wafat Mughirah terdapat perbedaan pendapat di kalangan kritikus hadis. Menurut Abu Na'im tahun 132 H, Ibn Main tahun 134, al-Ijli tahun 136, sedangkan menurut Ahmad ibn Hanbal dan Ibn Namir, Mughirah wafat pada tahun $133 \mathrm{~h}$ dan pendapat terakhir ini yang paling banyak. Ibid., jilid X, hlm. 232

\begin{tabular}{|c|c|c|c|}
\hline 5 & Ma'mar & 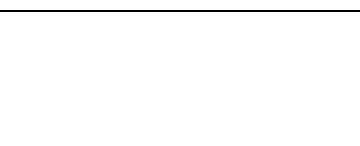 & - \\
\hline 6 & Abu Hatim dari Ahmad & - & يفف حريث \\
\hline 7 & $\begin{array}{l}\text { Ibn Abu Maryam } \\
\text { Dari ibn Main }\end{array}$ & فةمألةن & - \\
\hline 8 & Abu Hatim dari Main & مالمغلة اليفامن لصاد & - \\
\hline 9 & Ibn Abu Hatim & مغلةولنشاصةقةلن & - \\
\hline 10 & Al-'Tjli & مةقفيه الميث & يلول ئن \\
\hline 11 & Nasai & لقة & - \\
\hline 12 & $\begin{array}{l}\text { Ibn Fadhil dari } \\
\text { Bapaknya }\end{array}$ & كا لهل نذاكر تةت & - \\
\hline 13 & Ibn Sa’ad & قة كنة|إميث & - \\
\hline 14 & Ibn Hibban & - & مhl \\
\hline 15 & Ismail al-Radhi & - & ليسجوي \\
\hline
\end{tabular}

Berdasarkan penilaian yang diberikan kritikus hadis terhadap Mughirah sebagaimana yang terlihat pada tabel, maka dalam hal ini

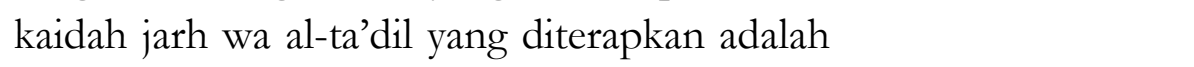
(menetapkannya sebagai ta'dil diutamakan daripada menetapkannya sebagai jarh). Hal ini karena meskipun terdapat yang mentajrih, namun yang ditajrih tersebut bukan melalui jalur Mughirah, tetapi melalui jalur Ibrahim, yang sama sekali tidak ada kaitannya dengan hadis yang sedang diteliti. 
Dengan demikian, maka Mughirah tetap dinilai sebagai perawi yang tsiqat.

5. Syu'bah

Nama lengkapnya adalah Syu'bah ibn Hajjaj ibn al-Ward al'Itkiy al-Azdiy al-Wasithiy al-Bishri. Lahir pada tahun $82 \mathrm{H}$ dan wafat di Bashrah pada tahun $160 \mathrm{H}$.

Syu'bah berguru kepada banyak ulama hadis, antara lain; Muhammad ibn Abd al-Jabbar al-Anshariy, Muhammad ibn Abd al-Rahman ibn Sa'id ibn Zaroroh, Muhammad ibn Abd al-Rahman, Ma'bad ibn Khalid, Mughirah ibn Miqsam, Abu Bakar ibn Abu hafash, Abu Sya'ib dan lain sebagainya. Sedangkan ulama yang meriwayatkan hadis darinya antara lain; Yahya al-Qaththan, Ibn Mahdiy, Musa ibn Yunus, Mu'az ibn Ma'az, Baqiyah ibn alWalid, Syarik al-Qadhi, Adam ibn Abu Iyas dan lain-lainnya. ${ }^{20}$

Abu Thalib berkata dari Ahmad, dalam masalah hukum, Syu'bah lebih tsabit dari al-A'masy dan lebih luas pengetahuannya di bidang hukum, sekiranya Syu'bah tidak ada maka kebanyakan hadis hukum akan lenyap, pada masanya tidak ada orang yang lebih baik pengetahuannya di bidang hadis selain Syu'bah; Ibn Mahdiy berkata, menurut al-Tsauriy, Syu'bah adalah amir al-mukminin fi alhadis; menurut Syafi'iy, kalau tidak karena Syu'bah, hadis tidak dikenal orang di Irak; Yazid ibn Zari' berkata, Syu'bah manusia yang paling jujur dalam bidang hadis; Muslim ibn Ibrahim berkata, saya selalu melihat Syu'bah sedang shalat meskipun bukan pada waktu shalat; Nadhar ibn Syamil berkata Syu'bah orang yang paling penyayang terhadap orang miskin; Yahya berkata, Syu'bah lebih banyak tahu rijal hadis yang terdapat pada hadis Sofyan dalam hadis yang diriwayatkan Sofyan; Daud berkata, ketika Syu'bah wafat Sofyan berkata hadis telah mati; Ibn Sa'ad berkata, Syu'bah itu tsiqat, dapat dipercaya, tsabit, hujjah dan shahib al-hadis; al-'Ijli

${ }^{20}$ Ibid., jilid IV, hlm. 297-301 berkata, Syu'bah itu tsiqat dan tsabit, tetapi ada sedikit kesalahan tentang nama-nama rijal; menurut Dar Quthniy, pada Syu'bah terdapat banyak kesalahan tentang nama rijal al-hadis karena ia sibuk dalam menghafal matan. ${ }^{21}$

Dari komentar ulama kritikus hadis dalam menilai Syu'bah, terdapat dua kategori saja yang mentajrihkannya, meskipun demikian kesalahan Syu'bah dalam hal sanad tersebut tidak diterangkan lagi lebih lanjut, maka dalam hal ini ta'dil dikedepankan.

\section{Baqiyah}

Nama lengkapnya adalah Baqiyah ibn al-Walid ibn Shaid ibn Ka'ab ibn Hariz al-Kila'iy al-Maitami Abu Yahmad al-Himshi.

Baqiyah meriwayatkan hadis dari; Muhammad ibn Ziyad alIlhaniy, Shafwan ibn Amr, Syu'bah, Hariz ibn Utsman dan lain sebagainya. Ulama yang meriwayatkan hadis dari Baqiyah adalah antara lain; Ibn 'Uyainah, Yazid ibn Harun, Ibn Mundzir alHimshiy dan lainnya. ${ }^{22}$ Sedangkan nama Muhammad ibn Mushaffa termasuk dalam kategori wa akharuna.

Menurut ibn Mubarok, ia (Baqiyah) adalah shaduq, tetapi ia menulis hadis dari orang yang lebih muda darinya dan juga dari orang yang lebih tua, apabila terhimpun Ismail ibn 'Iyasy dan Baqiyah dalam suatu hadis, maka saya pilih Baqiyah; Ibn 'Uyainah, jangan dengarkan riwayat Baqiyah dalam masalah sunnah, tapi dengarkanlah dalam masalah pahala dan lainnya; Ibn Ma'in berkata, Syu'bah sangat menghormati Baqiyah ketika sampai di Bagdad; Abdullah ibn Ahmad dari bapaknya, Baqiyah lebih aku sukai daripada Ismail, apabila ia meriwayatkan dari orang yang tidak dikenal, jangan terima; Yahya, apabila Baqiyah meriwayatkan dari

\footnotetext{
${ }^{21}$ Ibid., hlm. 301-302

${ }^{22}$ Ibid., jilid I, hlm. 416
} 
orang tsiqat maka terimalah; Yahya ibn Ma'in, Baqiyah meriwayatkan seratus hadis dari orang yang dhaif sebelum ia meriwayatkan hadis dari orang yang tsiqat; Ya'kub, ia tsiqat dan hadisnya hasan apabila ia meriwayatkan dari orang yang terkenal; Ibn Sa'ad, ia tsiqat bila meriwayatkan dari yang tsiqat dan dhaif bila meriwayatkan dari yang tidak dikenal; al-'Tjliy, tsiqat bila meriwayatkan dari yang tsiqat; Nasaiy, bila ia menggunakan lambang periwayatan haddatsana atau akhbarana maka dia tsiqat; Hakim, Baqiyah adalah tsiqat dan terpercaya. ${ }^{23}$

Ulama yang memberi komentar terhadap Baqiyah terdapat dua persi, ada yang menta'dilkannya dan ada pula yang mentajrihkannya, tapi keduanya punya kriteria dalam menilai, yakni menilainya sebagai tsiqah bila meriwayatkan dari yang tsiqat, dan dinilai bukan tsiqat bila meriwayatkan dari orang yang tidak dikenal. Dengan demikian, maka cacatnya Baqiyah adalah dalam periwayatannya bukan sifat yang terdapat pada dirinya, dan sifat pada dirinya lebih banyak menilai shaduq, makmun dan lain sebagainya. Dalam hal ini, maka kaidah jarb wa al-ta'dil yang diterapkan adalah

-( apabila terjadi pertentangan antara kritikan yang memuji dan yang mencela, maka yang harus dimenangkan adalah kritikan yang memuji, kecuali apabila kritikan yang mencela disertai penjelasan tentang sebab-sebabnya). Berdasarkan kaedah ini, maka dalam riwayat yang diteliti ini Baqiyah dinilai sebagai tsiqat karena ia meriwayatkan dari rawi yang tsiqat (Syu’bah).

7. Muhammad ibn Mushaffa

Nama lengkapnya adalah Muhammad ibn Mushaffa ibn Bahul al-Qurasyiy, Abu Abdillah al-Himshi al-Hafiz. Ia berangkat dari Himsh ke Makkah pada tahun $246 \mathrm{H}$ dan wafat di Mina.

${ }^{23}$ Ibid., hlm. 417-419
Muhammad ibn Mushaffa meriwayatkan hadis antara lain dari; bapaknya, Baqiyah ibn al-Walid, Abu Dhamrah, Utsman ibn Abdurrahman dan lainnya. Ulama yang meriwayatkan hadis darinya antara lain; Abu Daud, Nasaiy, Ibn Majah, Abu Abd al-Mulk alTastariy dan lainnya. ${ }^{24}$

Abu Hatim berkata, Dia shoduq; Nasaiy, Shaleh; Shalih ibn Muhammad, terdapat perbedaan dan saya berharap shoduq; Maslamah ibn Qasim, tsiqat dan masyhur; Nasaiy, shaduq. ${ }^{25}$

Berdasarkan komentar ulama terhadap Muhammad ibn Mushaffa di atas, maka yang menta'dilkannya lebih banyak daripada mentajrihkannya. Dengan demikian maka ia adalah periwayat yang dinilai adil.

\section{Umar ibn Hafsh}

Nama lengkapnya adalah Umar ibn Hafsh ibn Umar ibn Sa'ad ibn Malik al-Humairiy al-Washabiy, dan kadang disebut orang alAwshabiy al-Himshiy. Dia wafat pada tahun 246 H.26

Umar ibn Hafsh meriwayatkan hadis dari Baqiyah ibn alWalid, Ilyaman ibn 'Adiy, Sa'id ibn Musa al-Azdiy dan lainnya. Ulama yang meriwayatkan hadis darinya antara lain; Abu Daud, Abu Hatim, Ibn Abu 'Ashim, Ibn Abu Daud, 'Amr ibn Ishak dan lainnya. Ibnu al-Mawaq berkata, tidak diketahui keadaannya. ${ }^{27}$

\section{Abu Daud}

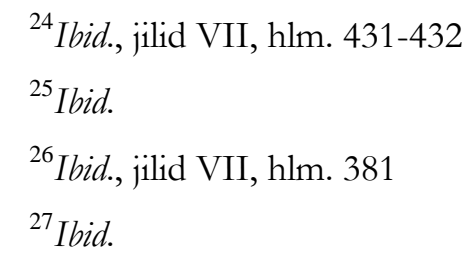


Nama lengkapnya adalah Sulaiman ibn al-Asy'ats ibn Syidad ibn 'Amr ibn 'Amir. Lahir pada tahun $202 \mathrm{H}$ dan wafat pada tahun $275 \mathrm{H}^{2}{ }^{28}$

Abu Daud meriwayatkan hadis dari Abu al-Walid al-Thayalisi, Muhammad ibn katsir al-'Abdi, Umar ibn Hafs, Muhammad ibn Mushaffa, Sulaiman ibn Abd al-Rahman al-Dimsyaqiy dan lainnya. Para muridnya antara lain; Abu Ali Muhammad ibn Ahmad ibn Amr al-LukluiyAbu Sa’id Ahmad ibn Muhammad ibn Ziyad alA’rabiy dal lainnya.

Maslamah ibn Qasim berkata, Abu Daud adalah tsiqat, zahid, mengetahui hadis dan imam hadis pada masanya; Ahmad ibn Muhammad ibn Yasin al-Harowiy, Abu Daud adalah salah seorang huffazh al-Islam di bidang hadis dan ilmunya, cacat atau tidaknya, dan tingkatan sanadnya tinggi. ${ }^{29}$

Tentang kualitas Abu Daud tidak diragukan lagi, karena selain sebagai periwayat hadis, beliau juga memiliki kitab hadis "Sunan Abu Daud", maka kemasyhuran beliau sudah dikenal.

\section{Al-Hukm 'Ala al-Hadis}

Dalam rangka menentukan kualitas hadis akan diarahkan pada dua sisi penilaian yang mendasar, yakni penilaian dari segi matn alhadis dan penilaian dari segi sanad al-hadis.

Yang menjadi standar dalam penelitian matan hadis secara umum adalah; bertentangan atau tidaknya dengan al-Qur'an, bertentangan atau tidaknya dengan hadis hadis mutawatir, bertentangan atau tidaknya dengan hadis lain yang kualitasnya lebih

\footnotetext{
${ }^{28}$ Ibid., jilid III, hlm. 457

${ }^{29}$ Ibid., hlm. 459
}

kuat, bertentangan atau tidaknya dengan akal sehat, bertentangan atau tidaknya dengan kaedah shaheh yang telah berlaku umum. ${ }^{30}$

Bila dilihat dari dilalah hadis ini, maka seolah-olah bertentangan dengan al-Qur'an, Surat al-Jumu'at ayat 9. Tetapi dalam hadis in terdapat kata rakhkhasa (diberi kelonggaran). Dengan demikian, maka jelas tidak bertentangan dengan al-Qur'an. Demikian pula tidak terdapat pertentangan dengan lainnya.

Berdasarkan langkah-langkah takhrij al-hadis yang dilakukan di atas, maka apabila dilihat dari segi kuantitas perawi hadis tentang adanya rukhsah meninggalkan shalat jum'at pada waktu hari raya sebagaimana yang telah dipaparkan dalam skema sanad gabungan dalam makalah ini, maka dapat dilihat setiap thabaqat terdapat tiga orang lebih perawi. Bila diikuti penilaian terhadap kuantitas perawi, maka hadis ini dapat dikatakan sebagai hadis mutawatir ma'nawi. Karena suatu hadis dapat dinilai mutawatir apabila diriwayatkan oleh tiga orang atau lebih pada setiap thabaqatnya. ${ }^{31}$

Kemudia bila dinilai berdasarkan kualitas sanadnya, maka hadis ini (khusus riwayat Abu daud yang telah diteliti) dapat dikatakan bersambung sanadya, perawinya dari tingkat sahabat sampai mukharrijnya dinilai 'adil, dhabith, juga tidak terdapat ilat dan syaz. Dengan demikian, bila mengikuti kriteria penilaian hadis berdasarkan kualitas sanadnya, maka hadis ini tergolong pada hadis sheheh.

Jika dilihat pada matan, maka matan hadis ini tidak bertentangan dengan nash al-Qur'an, juga tidak ada pertentangan dengan hadis mutawatir, juga tidak terdapat pertentangan dengan hadis lainnya yang kualitasnya lebih kuat, tidak terdapat pertentangan dengan logika sehat dan juga tidak terdapat pertentangan dengan dalil lainnya karena

${ }^{30}$ Musfar 'Azm Allah al-Damini, Maqayis Naqd Mutun al-Sunnah, (Riyad: Maktabah Su'udiyah, 1984), cet. I, hlm. 115

${ }^{31}$ Muhammad 'Ajaj al-Khatib, Ushul al-Hadis Ulumubu wa Musthalabubu, (Beirut: Daar al-Fikr, 1989), hlm. 301 
redaksinya dalam bentuk rukhsah. Dengan demikian, maka dapat pula dikatakan dari segi matan tidak terdapat pertentangan dan dapat dinilai shahih.

\section{Figh al-Hadis}

Landasan yuridis dalam masalah wajibnya shalat jum'at adalah berdasarkan al-Qur'an surat al-Jumu'ah, ayat 9;

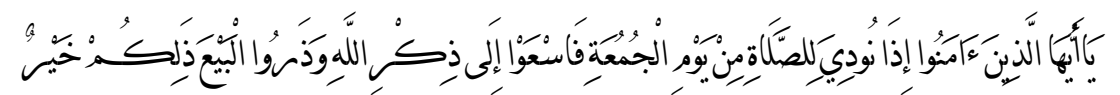

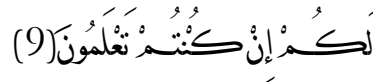

Artinya; Hai orang-orang yang beriman, apabila diseru untuk menunaikan sembahyang pada hari Jum 'at, maka bersegeralah kamu kepada mengingat Allah dan tinggalkanlah jual beli. Yang demikian itu lebih baik bagimu jika kamu mengetahui. (QS. Al-Jumu’ah; 9)

Dalam memahami ayat ini pada kata kerja dalam bentuk perintah (fiil amar) untuk mengingat Allah SWT (shalat) diartikan sebagai kewajiban. Adanya pengertian wajib di sini adalah karena ma'na amar tersebut tidak terdapat indikasi lain yang dapat memalingkan ma'nanya kepada selain wajib, maka kaidah ushuliyah yang diterapkan adalah

في لأمر للوجوب (pada dasarnya perintah itu menyatakan wajib). Demikian pula dipahami dari adanya larangan untuk mengadakan jual beli yang ketika turunnya ayat al-Qura'an ini merupakan pekerjaan umumnya masyarakat Arab. Dengan adanya larangan di sini, maka dapat dipahami berdasarkan kaidah ushuliyah tentang nahi نهي شيئ أمر.ضده (bila ada larangan untuk sesuatu, maka merupakan perintah untuk lawannya). Apabila melaksanakan aktivitas lain pada hari jum'at dilarang, maka berarti merupakan perintah untuk melaksanakan shalat

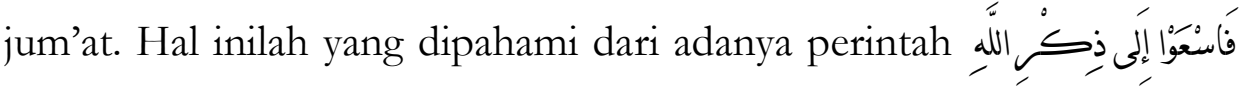
pada ayat di atas.

Masalah yang dibicarakan dalam hadis yang ditakhrij ini adalah masalah hukum melaksanakan shalat jum'at yang bertepatan dengan hari raya fitri maupun hari raya nahar.

Bila diperhatikan sebab munculnya hadis ini berdasarkan apa yang tercantum dalam hadis, maka hadis ini berkenaan dengan " abl al"awali" (penduduk dusun yang jauh) yang menurut perkiraan apabila mereka pulang ke dusun tempat mereka tinggal, mereka tidak akan dapat lagi kembali melaksanakan shalat jum'at bersama nabi.

Berdasarkan pemahaman terhadap adanya sebab munculnya hadis ini, maka kelonggaran yang diberikan nabi tersebut adalah untuk orang yang jauh dari pusat pelaksanaan shalat jum'at.

Bila dilihat dari teks hadis ini terdapat kata yang secara harfiah berarti “ memberi keringanan “. Dalam methodologi penetapan hukum Islam (ushul-al-figh) istilah keringanan ini disebut dengan " hukum rukhshah ".32 Hukum rukhshah ini merupakan pengecualian dari hukum 'ažimah yang baru dapat diterapkan apabila terdapat masyaqqah pada diri mukallaf yang apabila tetap diterapkan hukum 'azimah, maka paling kurang akan mendatangkan kesulitan. Sedangkan dalam prinsip-prinsip ajaran agama Islam salah satu di antaranya tidak memberikan kesulitan kepada mukallaf dalam menjalankan ajaran agama.

${ }^{32}$ Hukum rukhshah adalah hukum keringanan yang telah disyari'atkan Allah SWTT. kepada orang-orang mukallaf dalam kondisi-kondisi tertentu yang menghendaki keringanan; atau suatu yang telah disyari'atkan Allah SWT karena alasan kesulitan dalam suatu kondisi tertentu; atau juga membolehkan sesuatu yang terlarang karena adanya dalil, meskipun dalil larangan tersebut tetap berlaku. Lihat Abdul Wahab Khalaf, IImu Ushul al-Fiqh, alih bahasa oleh Masdar Helmi, (Bandung: Gema Risalah Press, 1997), hlm. 204 
Bila rukhshah tidak melaksanakan shalat jum'at yang bertepatan dengan hari raya ini, illat-nya adalah kesulitan, maka apabila diterapkan berdasarkan prinsip Qiyas, maka bila terdapat kesulitan-kesulitan lain yang dapat mendatangkan masyaqqah bila tetap melaksanakan shalat jum'at, maka rukhshah tetap berlaku baginya.

Sebagai perbandingan kita dapat merujuk bagaimana pendapat ulama mazhab dalam memahami masalah ini;

Syafii mengatakan rukhsah yang terdapat dalam hadis ini hanyalah rukhsah yang hanya diberikan kepada penduduk dusun yang jauh dari tempat melaksanakan jum'at, atau juga berlaku bagi orang yang berada di kota, tetapi ia punya udzur. Dengan demikian, maka menurutnya hukum ini tidak berlaku bagi orang yang mudah untuk melaksanakan jum'at. ${ }^{33}$

Menurut 'Atha' Apabila pada hari jum'at bertepatan dengan hari raya, maka shalat jum'at bukan hanya menjadi rukhsah, tetapi malahan menjadi tidak wajib lagi, karena shalat 'ied sudah dapat menutupi kewajiban jum'at.

Sedangkan menurut Abu Hanifah, hal ini tidak dapat diterapkan, karena keduanya punya hukum yang berbeda, shalat jum'at hukumnya wajib, sedangkan shalat hari raya hukumnya hanya sunat. Dengan demikian, maka ibadah yang wajib tidak dapat digugurkan oleh ibadah yang sunat, dengan kata lain kewajiban melaksanakan shalat jum'at tetap berlaku meskipun pada waktu hari raya. ${ }^{34}$

Ahmad ibn Hanbal berpendapat bila hari raya bertepatan dengan hari jum'at, maka tidak ada lagi kewajiban shalat jum'at baik bagi penduduk dusun yang jauh, maupun penduduk kota yang mudah

${ }^{33}$ Syafii, Al-Umm, (Beirut: Daar al-Kutub al-Ilmiyah, 1993) jilid I, hlm. 399

${ }^{34}$ Pendapat Abu Hanifah tersebut dikutip oleh Ibn Rusyd, Bidayat al-Mujtahid wa Nihayat al-Muqtashid, (Beirut: Daar al-Fikr, t.th.), jilid I, hlm. 159. Penjelasan tentang ini juga dapat dilihat Sayyid Sabiq, Fiqh al-Sunnah, (Beirut: Daar al-Fikr, 1995), jilid I, hlm. 239 untuk melaksanakan shalat jum'at, tetapi yang wajib hanya shalat dzuhur saja. ${ }^{35}$ Dengan demikian menurut Imam Ahmad Rukhshah ini diberikan kepada semua umat Islam, bukan hanya bagi orang yang ada masyaqqah. Keringanan ini hanyalah karena terdapatnya dua hari raya yang bersamaan pada satu hari.

Demikianlah pendapat ulama dalam mengomentari hadis tentang rukhsah meninggalkan shalat jum'at pada waktu hari raya yang tidak bisa dilepaskan dari perbedaan pendapat. Hal ini adalah karena perbedaan pendapat dalam memahami dalil dan juga berbeda dalam menerapkan dalil yang dipahami tersebut.

\section{Kesimpulan}

Demikianlah kajian kritik hadis tentang hukum melaksanakan shalat jum'at yang diupayakan berdasarkan metode yang telah ditetapkan. Semoga kajian takhrij al-hadis seperti ini dapat ditumbuh kembangkan kembali dalam rangka memahami hukum-hukum yang terdapat dalam hadis-hadis nabi. Kajian ini juga merupakan salah satu upaya agar umat tidak hanya menukil apa yang telah dikemukakan oleh ulama madzhab pendahulu, tetapi berupaya untuk menggali kembali pada sumber-sumber aslinya dengan menggunakan methodologi istimbath hukum dalam Islam.

\section{Bibliografi}

Abu Daud Sulaiman ibn al-Asy'ats al-Sijistani, Sunan Abu Daud, Jilid I, (Beirut: Daar al-Fikr, 1994)

35 Lihat penjelasan Ahmad ibn Hanbal sebagaimana yang dikutip oleh 'Allamah Abu al-Thayyib Muhammad Syams al-Haqq al-'Azhim Abadiy dan syeikh ibn al-Qayyim al-Jauziyah, 'Aun al-Ma'bud, Syarb Sunan Abu Daus, (Beirut: Daar alFikr, t.th),jilid 3, hlm. 409 
Asqalani, Imam al-Hafiz Syaikh al-Islam Syihab al-Din Ahmad ibn Ali ibn Hajar, Bulugh al-Maram min Adillat al-Abkam, (Semarang: Thaha Putra, t.th)

Tahdzৃib al-Tahdrib, Jilid I, III, IV, VII, X dan XII, (Beirut: Daar al-Fikr, 1984)

Bukhari, Muhammad ibn Ali ibn Tsabit al-Khatib, Shahib Bukhari, Jilid III, (Beirut: Daar al-Fikr, 1981)

Damini, Musfar 'Azm Allah, Maqayis Naqd Mutun al-Sunnah, (Riyadh: Maktabah Su'udiyah, 1984)

Ibn Majah, Abu 'Abd Allah Muhammad ibn Yazid al-Qazwini, Sunan Ibn Majah, Jilid I, (Beirut: Daar al-Fikr, 1995)

Ibn Rusyd, Bidayat al-Mujtabid wa Nibayat al-Muqtashid, Jilid I, (Beirut: Daar al-Fikr, t.th)

Khalaf, Abdul Wahab, Ilmu Ushul al-Fiqh, alih bahasa oleh Masdar Helmi, (Bandung: Gema Risalah Press, 1997)

Khatib, Muhammad 'Ajaj, Ushul al-Hadis Ulumubu wa Musthalabubu, (Beirut: Daar al-Fikr, 1989)

Sabiq, Sayyid, Fiqh al-Sunnah, Jilid I, (Beirut: Daar al-Fikr, 1995)

Suyuthi, Imam al-Hafizh Khadim al-Sunnah wa Qani’ al-Bid'ah Jalal al-Din 'Abdurrahman ibn Abu Bakar, Al-Jami' alShaghir fi Ahadits al-Basyar al-Nazariyah, (Singapura: Syirkah al-Nur Asia, t.th)

Syafi'i, Imam Abu Abd Allah Muhammad ibn Idris, Al-Umm, (Beirut: Daar al-Kutub al-Ilmiyah, 1993)

Syaltut, Mahmud, Al-Islam 'Aqidah wa Syari'ah, (Cairo: Daar al-Qolam, 1966)

Syams al-Haqq al-'Azhim Abadi, 'Allamah Abu al-Thayyib Muhammad dan al-Hafiz Ibn Qayyim al-Jauziyah,
'Aun al-Ma'bud, Syarb Sunan Abu Daud, Jilid III, (Beirut: Daar al-Fikr, t.th.)

Usman, Mukhlis, Kaidah-kaidah Ushuliyah dan Fiqhiyah, (Jakarta: Rajawali Pers, 1997)

Wensinck, A.J., Miftah Kunuz al-Sunnah, (Cairo: Daar alHadits, 1966)

, Mu'jam al-Mufabras li Alfazh al-Hadits al-Nabawiy, (Leiden: EJ. Brill, 1967) 